\title{
Quranic Literary Study: Sayyid Qutb's Thought and Orientation
}

\author{
Asyraf Hj Ab Rahman ${ }^{1}$, Wan Ibrahim Wan Ahmad ${ }^{2}$, Nooraihan $\mathrm{Ali}^{3}$ \& Daud Ismail ${ }^{3}$ \\ ${ }^{1}$ Centre for Fundamental and Liberal Education, Universiti Malaysia Terengganu, Malaysia \\ ${ }^{2}$ School of Social Development, Universiti Utara Malaysia, Malaysia \\ ${ }^{3}$ Faculty of Islamic Contemporary Studies, Universiti Sultan Zainal Abidin (UniSZA), Terengganu, Malaysia \\ Correspondence: Asyraf Hj Ab Rahman, Centre for Fundamental and Liberal Education, Universiti Malaysia \\ Terengganu, Malaysia. Tel: 60-9-668-3507.E-mail: asyraf@umt.edu.my
}

Received: October 3, 2014 Accepted: December 19, 2014 Online Published: January 14, 2015

doi:10.5539/ass.v11n4p218 URL: http://dx.doi.org/10.5539/ass.v11n4p218

\begin{abstract}
This paper looks into Sayyid Qutb's thought and his personal experiences in regards to the study of the Quran including its content and literary aspects during the years 1940 to 1945 and how this new orientation have had a great impact on Qutb's later writings. Data for the study is based on Qutb's works such as al Taswir al Fanni fil Quran, al Adalah al Ijtimaiyyah fil-Islam and Fi Zilal al Quran. These works considered fundamental and paramount in analysing Qutb's thought throughout those years as the Quran gradually motivated Qutb and his later views in regards to Islam and society as a whole. A descriptive analysis is employed by examining his works which manifest Qutb's thought besides identifying some major themes relevant to the study objectives.
\end{abstract}

Keywords: sayyid qutb, quranic studies, Egyptian society

\section{Introduction}

The twentieth century continued to witness the decline of the Muslim world in its society, economy and politics as compared to the West. Under the guise of socialism, nationalism and democracy, some political leaders of Muslim countries manipulated the uncertain political situation to keep their countries and their people in their grips. Unfortunately their idealism and proposed solution to some extents ignored the Islamic worldview. Realizing this phenomenon, there appeared some Muslim scholars (ulama') and thinkers in the early and mid-twentieth century who were concerned about the problems and tried to find solution from the Islamic and Quranic perspectives. Names like Jamal al-Din al-Afghani (d.1897), Muhammad Abduh (d.1905) and Rashid Rida (d.1935) were among those who saw that 'something must be done' to understand the causes of the decline so as to rectify the situation and restore Muslim countries to their proper place in the world. Following these scholars' footsteps, Sayyid Qutb bagan to see that the Quran had a solution for the problem by suggesting approaches to be observed by his fellow Muslims.

This paper looks into Sayyid Qutb's thought (1906-1966) and his personal orientation. Sayyid Qutb's importance stems from the fact that his thought was so influential not only in Egypt but also at the global level outside the Egyptian society. His thought was seen as a response to the actual Egyptian socio-political conditions during World War II and the post-war period, which led Egypt into a period of increasing violence, chaos and anarchy. There was a breakdown of law and order between 1945 and 1952, in which strikes broke out everywhere, including among industrial workers, public employees and the police force. This indicated clearly the disillusionment of the Egyptians with the government in power, which had failed to solve the country's pressing problems. They began to demand a social reform that would guarantee social justice put into practice (Musallam, 1983).

Qutb's interest in the Quran began since his early childhood. It was however in 1947, after his literary studies of the Qur'an from a literati's perspective then, his interest in Islam merge with his awareness of the prevailing social and political conditions. This new phase of his thought was manifested clearly in articles produced during years 1940 to 1947. Describing this new orientation in Qutb's thought, Nettler (1994) and Haddad (1983) noted that the Quranic usages by Qutb was more towards justifying his existing thought and thus putting him in the rank of Muslim thinkers. Nettler (1994) notes, 'the Quran served for Qutb as a court of last resort and the ultimate proof of his ideas'. As Muslim who sought for truth, Qutb's Quranic usage should be seen as part of his justification about the truth and validity of Islam. This was due to his preceding questions on the principles and 
standards of ancient and modern philosophers, Muslims and non-Muslims in regard to the meaning of life and several solutions to the prevailing social and political problem facing Egyptian society (Mousalli, 1992).

Among Qutb's major works, al Taswir al Fanni fil Quran, al Adalah al Ijtimaiyyah fil-Islam and Fi Zilal al Quran considered as paramount and fundamental since the works discussed Qutb's perspectives based on the Quranic points. According to Khalidi (1986), Qutb's prison experiences since 1954 onwards were extremely difficult for him, especially the first three years, for he was a generally sickly man who suffered from a number of afflictions. It is alleged also that he was made to undergo torture of various kinds. The experiences also enabled Qutb to see the real condition of the Muslims around him including the weakness in the faith of the Muslims and the loss of the spirit of the Qur'än in their hearts. This was apparent from their continuous and unfounded support of the unjust government, despite knowing about its oppression of Islamic groups and their fellow Muslims in particular. There was the Quran that opened Qutb's eyes to see the real Egyptian world and the existing unjust government. For Galford, Qutb's interest to the Quranic interpretation was part of the current trend of modern tafsir method that emphasizes on tafsir al-Quran bil Quran (interpreting the Quran using the Quran). 'Commentators this century are on the whole, if not unanimously, against the use of extra-Quranic materials...to elucidate the Quranic meaning..' (Galford, 1998).

\section{Materials and Method}

Data for this study is based on Qutb's works, al-Taswir al-Fanni fil Quran, al-Adalah al-Ijtima'iyyah fil-Islam and Fi Zilal al-Quran. Using content analysis technique and a descriptive approach, Qutb's personal experiences and his search for the truth manifested in his writing are reviewed and analysed. Content analysis refers to any technique for making inferences by objectively and systematically identifying specified characteristics of messages (Stemler, 2001). Review of secondary data from other scholars' works on Sayyid Qutb's thought and his works, are also analysed as to see their views and response in regards to Qutb's influences in the context of Muslim society. A descriptive analysis is employed by examining those works which manifest Qutb's thought besides identifying some major themes relevant to the study objectives.

\section{Results and Discussion}

\subsection{Qutb's Literary Analysis of the Qur'an}

Qutb's renewed interest in the Qur'an was, perhaps, manifest with the publication in 1939 of his earliest article entitled "al-Ta-wir al-Fanni fi'l-Qur'an" in Muqtataf magazine. In the introduction he stated: "The time has come to study the Qur'an as a literary book and to examine it from a completely artistic point of view." (Fayyad, 1976). Throughout the discussion, Qutb put more emphasis on the literary aspect of the Qur'an without any elaboration on the nature of the Book itself or any other social and political issues. Thus, his aim was to show the elements of beauty in its style so that writers might be influenced by it as Western writers were influenced by the Bible (Fayyad, 1976).

According to Khalidi, the seeds of Qutb's interest in the Qur'an can be dated from his childhood. At that stage Qutb's mother, Fatima, played an important role in implanting such an interest in him by making him listen carefully to Qur'anic recitations, especially during the month of Ramadhan when a reciter of the Qur'an was invited to their house. It was however during Qutb's years at Dar al- ${ }^{c}$ Ulum in the 1920s that his particular interest in the literary analysis of the Qur'an developed. This was due to his dissatisfaction with the institution's method of teaching the Qur'anic exegesis, which, according to him, was devoid of the enjoyment and excitement that he had experienced in his childhood (Khalidi, 1986). Therefore, the question arose in his mind: "Are there two Qur'ans: that of childhood, sweet, easy and exciting, and that of youth, difficult, complicated and dissected? Or is it rather the fault of the methods of interpretation?" (Qutb, 1994).

With this new idea in mind, Qutb then undertook to study the Qur'an not for the purpose of increasing his knowledge of religious matters but to examine the Qur'an's artistic imagery. Qutb clearly stated this renewed interest:

I have returned to the Qur'an by reading it, but not in the books of exegesis. And I have rediscovered my beloved and beautiful Qur'an, and found [again] my sweet and longing images-images without the original naivety [I attached to them]. I came now to comprehend its purposes and goals. (Qutb, 1994)

\subsection{Al-Taswir al Fanni fi Quran}

In Taswir (1994), Qutb discovered that the power of the Qur'an did not lie in a single sentence or expression, but in the whole style and method of conveying its religious message. Qutb cited many examples of the Qur'an's artistic imagery at its method of personification. This includes verse 18 of Sura 81 (al-Takwir), "wa'l-subh idha tanaffas" (By the morning when it breathes), which, according to him, was an expression of the peaceful quiet 
life coming from the morning's breath filling all creatures with activity (Qutb, 1992, 1994). Also in verse 40 of Sura 7 (al-A $\left.A^{c} r a f\right)$ :

Verily, those who believe our revelations and treat them with arrogance, for them the gates of Heaven will not be opened, and they will not enter Paradise until the camel goes through the eye of the needle. Thus do we recompense the sinners?

The abstract meaning of the Sura, according to Qutb, gave a sensual image in which the impossibility of the unbelievers entering Heaven was portrayed and likened to the impossibility of a camel entering a needle's eye (Qutb, 1992, 1994). Turning to the Qur'anic outlook on the afterlife, Qutb contended that the Qur'an portrayed the doomsday scenes in a dynamic way and thus greatly affected the human mind. According to him, the artistic portrayal by the Qur'an of the afterlife was indirectly successful in convincing the Arabs to believe in heaven and hell. At this point, Qutb started to consider the ability of the Qur'an to captivate the Arabs, who were renowned for their deep sensitivities and breadth of imagination. He then found that it was the charm of the Qur'anic literature that influenced them to believe in the Book and become Muslims. So, there emerged a new aim in Qutb's mind: to study the charm of the Qur'an in its role of propagating a religious message.

More significant is that Qutb's new interest in the Qur'an's artistic inimitability finally enabled him to understand the Book as a belief system and a guide for human life in all its aspects: social, economic and political. This can be seen with the appearance of his first Islamic book, al- $^{c}$ Adala al-Ijtima ${ }^{c}$ iyya fi'l-Islam, two years later in 1949. The book contained more than two hundred verses from the Qur'an to support his Islamic discussion covering all kinds of topics from doctrinal belief to social and economic questions. Thus, there was a clear sign of Qutb's new orientation after his eight years of devotion to the literary study of the Qur'an. More importantly, the Quran prepared him with a new intellectual outlook: his interest in Islam as a way of life. For Qutb, the importance of the Islamic concept (tasawwur) can be seen first in the Muslim's need for $\mathrm{s}$ comprehensive interpretation of existence which includes divinity, the universe, life and mankind. Thus, the political system that rules over human life becomes, for its validity, dependent on the comprehensive interpretation of the Islamic concept and values mentioned earlier.

Besides $a l-{ }^{\mathrm{c}}$ Adala, the appearance of Qutb's other works such as al-Salam al-alami and Ma rakat were also a clear indication of his development of thought as he began to put much emphasis on God as the Supreme Power and discuss extensively the concept of balance and integration of the universe, life and humankind. In describing Qutb's new Islamic orientation and his Qur'anic justification in solving the current socio-political problems of his society, Abu Rabic stated: "Qutb's utilization of the Qur'anic text as aesthetics paves the way for a more general and perhaps imaginative use of the text as an ideological document in the 1950 and 1960s." (Rabi, 1996).

\subsection{Reform Programmes and Islamic Solution}

Qutb's articles written in 1945 advocated issues related to social, economic and political reform. His objectives during this period were to expose the real situation of the Egyptian society and the need for reforms. None of his calling advocated "Islamic" solutions. Only in October 1947, after his long study of the Qur'an coupled with a consciousness of the national crisis, did he establish, with some friends, a weekly journal, al- Fikr al-Jadid (New Thought). The journal offered Islamic solutions to the social problems facing the country. The journal also attempt to bring people's attention to Islam instead of following capitalist and communist groups, who were active in spreading their reformative programmes for the Egyptians.

Qutb wrote in the journal that the time had come to look to Islam to solve the current problems in a practical and realistic manner, in true harmony with both an Islamic spirit and the contemporary human situation (Musallam, 1983). The journal, however, did not describe in detail the Islamic method of achieving justice in human social and economic welfare, such as the obligation to pay zakat etc. Rather, it focused more on a just distribution of wealth in Egypt, relations between landowners and workers, and between employers and employees in regard to wages and working hours (Musallam, 1983). This lack of any comprehensive Islamic solution was perhaps due to the short period of its appearance: it was published for only six months (October 1947 to May 1948) before being closed down owing to martial law being declared prior to the Palestine war.

Despite its short life, the journal successfully achieved its goals. The reform programmes advocated by the journal opened the minds of the Egyptians to the need to stand up to the privileged elite in their society and demand social justice the distribution of wealth, individual ownership and so on. As Heyworth-Dunne (1950) writes:

The journal promised to be one of the most interesting experiments of modern times, as it offered some real contributions by suggesting methods which could be employed for the solution of some of the acute social 
problems facing the Egyptian today. The editors also made it their duty to show up the real situation amongst the poor, both in the towns and in the country. He (Qutb) and his agents collected a number of detailed reports on the living conditions of their compatriots and published these with photographs.

Besides writing books like al-Adalah, Ma'rakat and al Salam al Alami, Qutb began joining the Ikhwan group and participated in its dakwah activities. It was during this stage that he was in close contact with the Free Officers in their intention of overthrowing the monarchy and the liberal nationalist regime. Despite different ideological principles (Socialism versus Islam), the growing crisis in Egyptian politics and the economy had led them to agree to co-operate in the struggle for unity and justice for the Egyptian people. In describing the social and political sphere of Egyptian society after World War II, Mitchell wrote that the crisis in the country grew worse and greatly affected the economic, political, and social life of the Egyptian people. More importantly, it "had manifold consequences for both the momentum and the direction of the national movement."(Mitchell, 1969) Therefore, "an agreement of sort" was reached later on between the Free Officers and the Ikhwan concerning the latter's role on the day of the revolution. This agreement "attempted to foresee all the possible contingencies in which a well-disciplined, well-trained civil army could be of use."

The revolution of July 1952 saw Qutb's emergence as one of its important figures. He played a vital role in influencing the people of the country and gaining their support. According to Mahmud al-Azab, an Egyptian military officer working at Port Said, Qutb played an instrumental role in the preparations. On the eve of the revolution, he commanded those military officers to be fully prepared. While attending the meeting held at Qutb's house, Mahmud al-Azab found that some of the revolutionary leaders were also there, including Jamal ${ }^{c}$ Abd al-Nasir. (Khalidi, 1986). In additions to his direct participation in the 1952 revolution, Qutb also wrote books and articles criticizing the corrupt royal government, feudalism and capitalism. This indicated that Qutb tried to implement what he believed as a true struggle as enunciated by his religious teaching; combating injustice in human society and affirmed the capacity of Islam as an appropriate and desirable ideology for the world of the mid-twentieth century. Qutb wrote in $\mathrm{Ma}^{c}$ rakat, for instance: "the deterioration in social conditions from which the masses of Egypt suffer cannot continue indefinitely... This is a fact that should be known by all.

Of all Qutb's early works, Zilal was his masterpiece. It tacked all the issues in more details approaching topics on society, economic and politics on the basis of the Quran. Throughout his discussion about Islamic way of life manifested in Zilal, Qutb employed an educational approach to human conscience believing that to be the best to bring people close to God. This is because with the fear of God in one's heart, individuals will not only refrain from committing $\sin$ in public, but will also behave appropriately in private since he knows that God sees all His servant's deeds and actions wherever they are.

\section{Conclusion}

The twentieth century continued to witness the decline of the Muslim world in its society, economy and politics including Egypt. Qutb's socio-religious thought from 1947 to 1952 paralleled the social and political situation of Egyptian society itself. World War II and the post-war period were major factors that led the country into social, economic and political chaos and anarchy. Qutb, who identified himself with the social and religious concerns of the people, had become extremely disillusioned with the prevailing social ills and political system. His literary study of the Qur'an coupled with his disillusionment gradually compelled him to find in Islam the solution to the current problems. Qutb's approach in solving the current socio political issues facing his society differed from his other contemporary fellow Muslims in the sense that he viewed the Quran as having the power which not lie in a single sentence or expression, but in the whole style and method of conveying its religious message. In Taswir, Qutb found that it was the charm of the Qur'anic literature that influenced some Arabs to believe in the Book and become Muslims. Thus, using this understanding he proposed a similar approach to be followed by other fellow Muslims in treating the current socio political problem facing Muslim society. For Qutb, educational approach on the basis of understanding and examining the Qur'an's artistic imagery is vital to human conscience believing that to be the best to bring people close to Allah. Qutb's later works, Al- $^{c}$ Adala, Ma rakat and al-Salam al-A $A^{a}$ ami were a detailed analysis of these problems from the Islamic and Quranic viewpoint. Of all Qutb's works, Zilal considered as Qutb's masterpiece as it tacked all the issues in more details approaching topics on society, economic and politics on the basis of the Quran.

\section{References}

Dunne, J. H. (1950). Religion and Political Trends in Modern Egypt. Washington D. C.

Fayyad, S. (1976). The Study of Qutb's thought and his literature. Unpublished Ph.D thesis University of Manchester. 
Galford, H. S. (1998). Sayyid Qutb and the Quranic Story of Joseph: A Commentary for Today. Studies in Muslim-Jewish Relation, 4, 39-64.

Haddad, Y. Y. (1983). The Quranic Justification for an Islamic Revolution: The View of Sayyid Qutb. The Middle East Journal, 37(1), 17.

Khalidi, S. A. A. (1986). Madkhal ila Zilal al-Qur'an. Jeddah: Dar al-Manara.

Mitchell, R. (1969). The Society of Muslim Brothers. London: Oxford University Press.

Mousalli, A. S. (1992). Radical Islamic Fundamentalism: The Ideological and Political Discourse of Sayyid Qutb. Beirut: American University of Beirut.

Nettler, R. (1994). A Modern Islamic Confession of faith and Conception of Religion: Sayydi Qutb's Introduction to tafseer Fi Zilal al Quran. British Journal of Middle Eastern Studie, 21(1), 102-110. http://dx.doi.org/10.1080/13530199408705594

Qutb, S. (1952). al- ${ }^{c}$ Adala al-Ijtima ${ }^{c}$ iyya fi 'l-Islam. Cairo: Matba ${ }^{\mathrm{c}}$ a Dar al-Kitab al- ${ }^{\mathrm{C}}$ Arabi.

Qutb, S. (1982). Khasa'is·al-Tasawwur al-Islami. Beirut: Dar al-Shuruq.

Qutb, S. (1992). Fi Zilal al Quran. Cairo: Dar al Shuruq.

Qutb, S. (1993). Islam and Universal Peace. Indianapolis: American Trust Publications.

Qutb, S. (1993). Macrakat al-Islam wa'l-Ra'smaliyyah. Cairo: Dar al-Shuruq

Qutb, S. (1993). Mashahid al-Qiyama fi'l-Qur'an. Cairo: Dar al-Shuruq.

Qutb, S. (1993). Nahw Mujtamac Islami . Cairo: Dar al-Shuruq.

Qutb, S. (1994). Al-Taswir al-Fanni fil Quran. Cairo: Dar al-Maarif.

Rabi ${ }^{\mathrm{c}}$, A., \& Ibrahim, M. (1996). Intellectual Origins of Islamic Resurgence in the Modern Arab World. Albany: State University of New York Press.

Stemler, S. (2001). An overview of content analysis. Practical Assessment, Research \& Evaluation, 7(17). Retrieved December 17, 2014 from http://PAREonline.net/getvn.asp

\section{Copyrights}

Copyright for this article is retained by the author(s), with first publication rights granted to the journal.

This is an open-access article distributed under the terms and conditions of the Creative Commons Attribution license (http://creativecommons.org/licenses/by/3.0/). 